\title{
IMPACT OF RESIDENTIAL HEATING COSTS ON THEIR VALUE
}

Marta Nalewajko, BEng, MSC (ORCID: 0000-0002-2458-7147) - Bialystok University of Technology, Faculty of Civil Engineering and Environmental Sciences

Correspondence address:

Wiejska Street 45E, Białystok, 15-351, Poland

e-mail:m.nalewajko@pb.edu.pl

ABSTRACT: This article deals with the essence of the influence of factors related to various heat sources on property valuation. The study's main aim is to show that the applied heating system impacts the costs of maintaining and operating a building. A thesis was made that the type of heat source used to heat the property is a factor that significantly influences the value because its efficiency and general characteristics can significantly affect the amount of the building's operating costs. For this reason, the method of heating building objects should be an attribute taken into account during the valuation carried out by a property appraiser.

KEYWORDS: building real estate, real estate appraisal, real estate value, building heating costs 


\section{Introduction}

In the era of the development of new technological solutions, contemporary housing construction is designed to provide the basic housing needs of the population and create the required comfort of use. Investors pay more and more attention, for example, to the heating systems used, taking into account not only the environmental protection aspects but, above all, the maintenance costs of the facility during its operation. There is no doubt that factors related to different heat sources in residential buildings impact their value and should be considered in the valuation process. Analyzing the literature on the subject and the legal basis for real estate valuation in the form of the Real Estate Management Act and the Regulation of the Council of Ministers on the valuation and preparation of the appraisal report, it is clear that there is a specific group of attributes taken into account in the valuation process. Unfortunately, none of the estimation methods takes into account the factors related to the heat sources used. However, there is no doubt that when buying real estate, the heating method that affects the cost of maintaining a building is an important element in the decision-making process. This article is to prove the validity of the thesis. The community of real estate appraisers could consider whether it would be worth considering the heating method as one of the attributes influencing the value in the valuation process.

\section{Analysis of the installation costs of selected building heating systems}

Buildings consume over $40 \%$ of the overall energy consumed globally and play a significant role in sustaining electric grid power balance; therefore, it is very important to choose the right heating system (Alimohammadisagvand et al., 2016). When choosing a building heating system, the investor decides what fuel to use to ensure optimal thermal comfort at a reasonable price during the heating period. Additionally, the choice of heat supply options in new residential areas depends on various factors, including available local energy resources, their market prices and the scale and density of heat demand in these areas (Truong, Gustavsson, 2019). In addition, it is important to analyze the investment costs associated with the purchase and installation of a heating system. Therefore, the overview of selected heating systems presented below depends on the price of heating power, device efficiency, brand and others. 


\section{The heat from combined heat and power plants}

The use of energy from combined heat and power plants for the heating of buildings is the most common type of heating in Poland. This method is a convenient solution, especially in large cities, where the district heating network is well developed. Furthermore, the user of this system can enjoy the comfort of not purchasing and storing fuel, maintaining thermal devices, or, for example, removing ash.

Outside the city limits and large housing estates, access to heat network connections is significantly difficult. Construction of district heating mains in suburban areas, where single-family housing is dispersed, may turn out to be unprofitable. Initial expenses are the purchase of radiators and installation inside the building. The prices of radiators vary, but the cheapest of them cost about PLN 200 per piece (panel radiators). Another important issue affecting the profitability of the project is the offered tariff rate for the supplied energy. The table below shows the net prices for 1 running meter of the connection depending on the standard and the capacity of the main pipe - internal nominal diameter - Dn.

Table 1. Price list for the connection to the MPEC thermal network in Bialystok

\begin{tabular}{llll}
\hline No. & $\begin{array}{l}\text { Types of fee rates depending } \\
\text { on the diameter of the connection }\end{array}$ & $\begin{array}{l}\text { Unit } \\
\text { measures }\end{array}$ & $\begin{array}{l}\text { Net price } \\
\text { [in PLN] }\end{array}$ \\
\hline 1 & Dn 25 & PLN/m & 215,57 \\
\hline 2 & Dn 32 & PLN/m & 216,21 \\
\hline 3 & Dn 40 & PLN/m & 229,75 \\
\hline 4 & Dn 50 & PLN/m & 249,73 \\
\hline 5 & Dn 65 & PLN/m & 264,81 \\
\hline 6 & Dn 80 & PLN/m & 303,25 \\
\hline 7 & Dn 100 & PLN/m & 341,42 \\
\hline 8 & Dn 125 & $\mathrm{PLN} / \mathrm{m}$ & 448,56 \\
\hline 9 & Dn 150 & $\mathrm{PLN} / \mathrm{m}$ & 510,59 \\
\hline
\end{tabular}

Source: http://www.mpec.bialystok.pl/kategorie,86.html [27/06/2021].

\section{Coal-fired boilers}

Despite the extensive promotion of ecological energy sources and attempts to reduce the so-called low emission still, a very common method of heating real estate in Poland is coal-fired boilers. The significant advantage of 
this solution is the relatively low installation cost. Due to the purchase price, hard coal boilers can be divided into three categories:

Low price group. There are charging boilers operated by hand, with the natural draft, with upper or lower flue gas discharge, coal-fired in the sort of cubes or nuts. The best devices in this group are characterized by a theoretical efficiency of up to $70 \%$.

Average price group. There are charging boilers, operated manually, equipped with air blows. In the case of the bottom flue gas discharge, they are fed with lump coal (walnut or cube); in the case of the upper flue gas discharge, they are fired with pea coal or fine coal. The best devices in this group are characterized by a theoretical efficiency of up to $85 \%$.

High price group. It includes automatic boilers equipped with an air blower, fired with pea or fine coal. The most effective devices in this group achieve theoretical efficiency of up to $90 \%$ (Zawistowski, Janiszewski, 2010).

Table 2. Costs of exemplary boilers fired with coal, fine coal, wood, eco-pea coal

\begin{tabular}{lllll}
\hline Make, type & Type of coal & $\begin{array}{l}\text { Heating power } \\
\text { [in kW] }\end{array}$ & $\begin{array}{l}\text { Boiler efficiency } \\
\text { [in \%] }\end{array}$ & $\begin{array}{l}\text { Gross price } \\
\text { [in PLN] }\end{array}$ \\
\hline $\begin{array}{l}\text { Tomiterm - } \\
\text { PLESZEW BOILER }\end{array}$ & coal, fines, wood & $11-27$ & $82-88$ & from 5,000 \\
\hline $\begin{array}{l}\text { MALKOT, } \\
\text { MALINA PREMIUM }\end{array}$ & eko-pea coal & $9-48$ & $80-90$ & from 8,000 \\
\hline $\begin{array}{l}\text { DEFRO, } \\
\text { OPTIMA COMFORT }\end{array}$ & $\begin{array}{l}\text { coal, fines, wood, } \\
\text { chips }\end{array}$ & $8-58$ & $80-90$ & from 12,000 \\
\hline
\end{tabular}

Source: own study based on current information from sellers of heating boilers [27/06/2021]

\section{LPG-fired boilers}

With modern condensing boilers, natural gas consumption in the central heating installation is relatively low because they can receive more heat from the flue gas than traditional boilers. Thus, they are characterized by greater efficiency (Kosieradzki, 2009). In the absence of access to the gas network, the cost of purchasing a gas-fired boiler and implementing a complete central heating installation. The purchasing costs or leasing costs of a container for storing this fuel should be added.

The purchase of an LPG gas tank is associated with a large expenditure of PLN 6,000 to PLN 10,000. Having your own tank involves the choice of a good supplier, the necessity to take care of the proper functioning and servicing of the device on your own, as well as refilling the gas level on your own. The advantage of this solution is independence from a single gas supplier. 
A convenient way to provide gas for household needs without having to deal with technical service and constant ordering and refilling of fuel is the lease of such a tank.

Table 3. Costs of sample LPG-fired boilers

\begin{tabular}{llll}
\hline Make, type & $\begin{array}{l}\text { Heating power } \\
\text { [in kW] }\end{array}$ & $\begin{array}{l}\text { Boiler efficiency } \\
\text { [in \%] }\end{array}$ & $\begin{array}{l}\text { Gross price } \\
\text { [in PLN] }\end{array}$ \\
\hline ARISTON, CLAS B, 24BFFI & 22 & 108 & from 6,800 \\
\hline TERMET SILVER 1 & 35 & 109 & from 3,800 \\
\hline ARISTON, GENUS PREMIUM 35FF & 31 & 107.20 & from 8,700 \\
\hline
\end{tabular}

Source: own study based on current information from sellers of heating boilers [27/06/2021].

\section{Biomass-fired boilers}

Biomass fired boilers are currently the most advanced boilers in terms of design. They are equipped with mechanisms allowing for almost maintenance-free operation for a long period.

Table 4. Costs of exemplary biomass-fired boilers

\begin{tabular}{lllll}
\hline Make, type & Type of biomass & $\begin{array}{l}\text { Heating power [in } \\
\mathrm{kW}]\end{array}$ & $\begin{array}{l}\text { Boiler efficiency } \\
\text { [in \%] }\end{array}$ & $\begin{array}{l}\text { Gross price } \\
\text { [in PLN] }\end{array}$ \\
\hline STALKOT KWM-SGR & pellet & 19 & 82.70 & from 6,400 \\
\hline SAS AGRO-ECO & pellet & $17-23$ & 82 & from 14,520 \\
\hline TROTEX 25 & pellet, chips, wood & 25 & $86-88$ & 7,300 \\
\hline
\end{tabular}

Source: own study based on current information from sellers of heating boilers [27/06/2021].

\section{Heat pumps}

Heat pumps are considered to be easy to operate and, at the same time, use the possibility of bringing low-temperature heat sources to a higher temperature. Therefore, they can be used to reduce the need for fossil fuels and greenhouse gas emissions. Their great advantage is the power supply for both heating and cooling and the possibility of working in a simultaneous mode. It means that virtually no heat is dissipated, making such systems truly efficient (Osterman, Stritih, 2021). The investment cost of installing a heat pump depends on many factors. The conditions for obtaining heat in a given area are an important issue here. It often happens that the costs of producing 
a heat source and the costs of earthworks are comparable to the devices' price.

Table 5. Costs of making a heat source for a pump with a power of $10 \mathrm{~kW}$

\begin{tabular}{lll}
\hline Type of heat source & Costs [in PLN] & Comments \\
\hline Flat collector & $5,000-10,000$ & No earthworks costs \\
\hline Vertical probes & $10,000-15,000$ & Total cost \\
\hline Wells & $15,000-20,000$ & Total cost \\
\hline Air & $2,000-5,000$ & Pump inside the building \\
\hline Air & 0 & Pump outside the building \\
\hline
\end{tabular}

Source: (Oszczak, 2011, p. 44).

There is also the choice of the heat pump. The price difference between the most expensive pump and the cheapest one can be up to $100 \%$ (with the same heating power). More expensive pumps, as a rule, are more durable and more economical (Adamczewski, 2010).

Table 6. Costs of exemplary heat pumps

\begin{tabular}{lllll}
\hline Make, type & Source of heat & Power range [kW] & COP & $\begin{array}{l}\text { Gross price } \\
\text { [in PLN] }\end{array}$ \\
\hline NIBE SPLIT & air / water & $3-16$ & 4.4 & 29,000 \\
\hline EXOTHERM 30KW & brine / water & 30 & 5.5 & 35,150 \\
\hline STIEBELELTRON WPL13/18/23E & air / water & $7.7-17.1$ & 3.3 & up to 41,950 \\
\hline
\end{tabular}

Source: own study based on current information from heat pump sellers [27/06/2021]

\section{Solar panels}

Installing solar collectors is an ecological and modern way of obtaining heat for heating residential buildings. These devices are now technologically well-developed and allow for savings in operation. Unfortunately, solar systems are still relatively expensive. The cost of the installation depends on the demand for domestic hot water. Standard solar collectors can provide about $60 \%$ of the annual demand for domestic hot water. The cost of installing this technology can pay off after 5-8 years (but only if the purchase is subsidized). The investment turns out to be completely unprofitable in economic terms if the user pays for the collectors himself. In addition, you should bear in mind 
the expenses related to periodic inspections. The cost of inspections will be around PLN 150-300 / year (Solar collectors).

The minimum cost of installing solar collectors for a house used by a family of four is about PLN 10,000. This price includes installing and installing flat plate collectors from the lowest price range, e.g. Hewalex 2TLP-250C. More technically advanced devices with vacuum collectors and a selective absorber can cost about PLN 14,000. The prices of vacuum collectors with a heat pipe start from about PLN 18,000. Each extension of the functionality of the collectors or their integration with other heating systems will result in higher costs. The upper limit of financial expenditure on this type of equipment is difficult to define and depends on many factors (http://kb.pl/teksty/2017/01/25/kolektor-sloneczne-do-domu-jednorodzinnego/).

Table 7. Costs of sample solar collectors

\begin{tabular}{|c|c|c|c|c|}
\hline Make, type & The composition of the kit & $\begin{array}{l}\text { Efficiency } \\
\text { [in\%] }\end{array}$ & $\begin{array}{l}\text { Optical } \\
\text { efficiency }\end{array}$ & $\begin{array}{l}\text { Gross } \\
\text { price } \\
\text { [in PLN] }\end{array}$ \\
\hline $\begin{array}{l}\text { Hewalex } 2 \\
\text { TLP-250C }\end{array}$ & $\begin{array}{l}2 \text { flat plate collectors, KS2000 TLP type with a total } \\
\text { (active) aperture area of } 3.6 \mathrm{~m}^{2} \text { and a 2-coil hot } \\
\text { water heater with a capacity of } 250 \text { liters }\end{array}$ & 64 & 0.802 & 7,780 \\
\hline $\begin{array}{l}\text { Hewalex } 3 \\
\text { KSR10-250 }\end{array}$ & $\begin{array}{l}3 \text { vacuum collectors type KSR10 with a total } \\
\text { aperture area (active) } 3.0 \mathrm{~m}^{2} \text { and a 2-coil water } \\
\text { heater with a capacity of } 250 \text { liters }\end{array}$ & 73 & 0.780 & 11,570 \\
\hline
\end{tabular}

Source: own study based on current information of solar collector sellers [27/06/2021].

The solar set price does not include the cost of installing the collectors, which depends on the complexity and size of the installation, the degree of integration with another heating installation, the method of routing the solar pipes, and the type of roofing.

Depending on the above factors, the installation price ranges from PLN 1,500 to PLN 3,000 (http://www.instalacjebudowlane.pl/6770-23-55-jaki-jest-koszt-kolektorow-sloneczne.html).

In large installations, where collectors, for example, heat the water in the swimming pool, the economic sense of the investment is justified to a large extent. On the other hand, in small installations (e.g. in small single-family houses), where daily water consumption at $45^{\circ} \mathrm{C}$ is about $200-240 \mathrm{l}$, profitability depends on the price of supplied energy (the most expensive are electricity, fuel oil and LPG), growth fuel prices on the market, the amount of the subsidy. It is possible to use the subsidy from the National Fund for Environmental Protection and Water Management (NFOŚiGW), which offers a dona- 
tion of $45 \%$ of the loan amount taken for the installation of collectors; however, income tax must be paid on this subsidy (http://www.budujemydom. $\mathrm{pl} /$ kolekty-sloneczne/13063-czy-oplaca-sie-instalowac-solary).

Summing up, it should be said that the prices of heating systems differ from each other depending on the brand, type of device, or the efficiency and heating power. Devices using renewable heat sources are a more expensive investment in comparison to boilers fired with solid fuels. However, with the development of the market sector offering unconventional energy, one should expect more and more competitive prices of modern devices generating the so-called clean energy.

\section{Analysis of the operating costs of selected building heating systems}

In order to determine the costs of heating a property with its own independent heat source, the following parameters should be analyzed: the current price of the energy carrier, the calorific value of the fuel, the efficiency of the heating system and the heat demand of the building.

\section{Prices of energy carriers}

The cost of fuel used to heat a residential building is a very important factor that is influenced by many factors. The price, in this case, depends on the offers and tariffs of local suppliers. However, a wide selection of energy resources and the emerging competition on the supplier market means that the prices of the offered fuels may sometimes turn out to be attractive. The table below shows the average prices of the fuels used.

Table 8. Costs of fuels offered in Poland

\begin{tabular}{ll}
\hline Fuel Type & Unit price \\
\hline natural gas & $2.35 \mathrm{PLN} / \mathrm{m}^{3}$ \\
\hline LPG gas & $2.40 \mathrm{PLN} / \mathrm{I}$ \\
\hline LPG gas (tank lease) & $4.50 \mathrm{PLN} / \mathrm{I}$ \\
\hline heating oil & $3.35 \mathrm{PLN} / \mathrm{l}$ \\
\hline hard coal of the eco-pea type & $1000 \mathrm{PLN} / \mathrm{t}$ \\
\hline hard coal of fine type & $650 \mathrm{PLN} / \mathrm{t}$ \\
\hline pellet & $950 \mathrm{PLN} / \mathrm{t}$ \\
\hline electricity & $0.74 \mathrm{PLN} / \mathrm{kWh}$ \\
\hline
\end{tabular}

Source: own study based on current information from fuel suppliers [27/06/2021]. 


\section{Fuel calorific values}

Fuel calorific value [MJ/unit] is the energy obtained from fuel combustion related to its quantity (mass), assuming that the combustion is complete and the water vapour released with the exhaust gas is not condensed.

Table 9. Calorific values of various fuels

\begin{tabular}{ll}
\hline Fuel Type & Calorific value \\
\hline natural gas & $37.6 \mathrm{MJ} / \mathrm{m}^{3}$ \\
\hline LPG gas & $43.5 \mathrm{MJ} / \mathrm{l}$ \\
\hline heating oil & $42.6 \mathrm{MJ} / \mathrm{l}$ \\
\hline coal & $30 \mathrm{MJ} / \mathrm{kg}$ \\
\hline hard coal of fine type & $32.7 \mathrm{MJ} / \mathrm{kg}$ \\
\hline pellet & $18 \mathrm{MJ} / \mathrm{kg}$ \\
\hline
\end{tabular}

Source: own study based on current information from fuel suppliers [27/06/2021]

\section{The house's need for heat}

On January 1, 2009, the Ministry of Infrastructure adopted a regulation according to which each building and apartment should have its energy certificate, covering the necessary scope of information for its users and possible records. The energy certificate contains an assessment of the estimated amount of energy needed for heating, lighting, ventilation, and air conditioning of the building and domestic hot water preparation. The basic measure in this system is the total energy demand of the property during the year, converted to $1 \mathrm{~m}^{2}$ of its area $\left[\mathrm{kWh} / \mathrm{m}^{2} /\right.$ year]. A building is considered energy-efficient when the energy consumption is $70-100 \mathrm{kWh} / \mathrm{m}^{2} /$ year (Juliszewski, 2009).

According to the PN-EN ISO 13790: 2009 standard, the energy demand of real estate is the heat that should be supplied to maintain the intended thermal conditions.

Determining the heating costs of a residential building per year is a difficult task, requiring knowledge of many data. Information on this is provided in the building's energy performance certificate.

Annual expenses for heating a building real estate depend on the price of the energy carrier, its calorific value, the type and efficiency of the heating system and the building's heat demand. Therefore, choosing the most effec- 
tive and optimal heating solution requires comparing and comparing the operating costs of various heat sources.

Table 10. Energy standards adopted for buildings in Poland

\begin{tabular}{ll}
\hline The period of building a house & Energy demand $\left[\mathrm{kWh} / \mathrm{m}^{2} /\right.$ year $]$ \\
\hline Houses built until 1967 & $240-350$ \\
\hline Houses from 1968 to 1985 & $240-290$ \\
\hline Houses from 1986-1992 & $160-200$ \\
\hline Houses from 1993-1997 & $120-160$ \\
\hline Houses built since 1998. & $90-120$ \\
\hline Energy-efficient houses & $\max 70$ \\
\hline Low-energy houses & $\max 45$ \\
\hline Passive houses & $\max 15$ \\
\hline Zero-energy houses & $\max 0$ \\
\hline
\end{tabular}

Source: Polish National Energy Conservation Agency.

The table 11 shows the annual heating costs of a building property with $150 \mathrm{~m}^{2}$ with selected heat sources, taking into account the data provided and the division into different energy standards of the building.

Table 11. Annual heating costs of a building property with an area of $150 \mathrm{~m}^{2}$ with the various heat source [PLN]

\begin{tabular}{llllllll}
\hline $\begin{array}{l}\text { Type of heating } \\
\text { device }\end{array}$ & $\begin{array}{l}\text { Gas } \\
\text { condens- } \\
\text { ing boiler }\end{array}$ & $\begin{array}{l}\text { Condens- } \\
\text { ing boiler } \\
\text { for LPG }\end{array}$ & $\begin{array}{l}\text { Condens- } \\
\text { ing boiler } \\
\text { for LPG }\end{array}$ & $\begin{array}{l}\text { Cauldron } \\
\text { for heat- } \\
\text { ing oil }\end{array}$ & $\begin{array}{l}\text { Cauldron } \\
\text { for pellets }\end{array}$ & $\begin{array}{l}\text { Cauldron } \\
\text { for coal } \\
\text { - eco-pea } \\
\text { coal }\end{array}$ & $\begin{array}{l}\text { Brine / } \\
\text { water } \\
\text { heat } \\
\text { pump }\end{array}$ \\
\hline $\begin{array}{l}\text { Fuel Type } \\
\text { natural } \\
\text { gas }\end{array}$ & LPG gas & $\begin{array}{l}\text { LPG gas } \\
\text { (leased } \\
\text { installa- } \\
\text { tion) }\end{array}$ & heating oil & pellet & $\begin{array}{l}\text { eco-pea } \\
\text { coal }\end{array}$ & electricity \\
\hline $\begin{array}{l}\text { Annual heating } \\
\text { cost (well insu- } \\
\text { lated building) }\end{array}$ & 2,911 & 3,237 & 5,958 & 4,940 & 2,347 & 2,075 & 1,460 \\
\hline $\begin{array}{l}\text { Annual heating } \\
\text { cost (poorly } \\
\text { insulated } \\
\text { building) }\end{array}$ & 4,528 & 5,036 & 9,269 & 7,684 & 3,651 & 3,228 & 2,271 \\
\hline
\end{tabular}

Source: own study based on current information from fuel suppliers [27/06/2021]. 


\section{Selection of the most favourable heating method}

This analysis presents selected thermal systems used to heat residential buildings along with their installation and operating prices. The most optimal heat source selection is associated with a thorough analysis of information about heating technologies and energy raw materials available on the market. It would be best if you also considered the type and characteristics of your property to match a heating system that is the most efficient, economical and safe to operate. In this case, the volume and structure of the property, its location (free-standing or compact building), the region and its climatic features, the presence of utilities such as municipal heating network or gas network installation in the vicinity are important. The factor determining the purchase of a specific heating system in practice is also the investor's financial capacity and expectations regarding the effectiveness and efficiency of the heat source.

In order to consider the selection of the most advantageous method of heating a residential building property, certain criteria should be adopted. Undoubtedly, operating costs are of great importance here. In the light of the analysis, the cheapest solutions during operation are a brine/water heat pump, a coal-fired boiler and a pellet-fired boiler.

The heat pump requires a high investment in the installation phase. Depending on many factors, the cost of purchasing and installing such a system can reach up to 60,000. PLN (www.tendeo.pl). Suppose the investor is able to cover these costs and decides to use a heat pump as a means of heating the property. In that case, he will be able to experience the many advantages of using this efficient heating system in the future.

The use of a coal-fired boiler is contrary to the idea of supporting ecology and the principles of environmental protection but still common. The operating costs resulting from heating with coal are not prohibitive compared to the operational costs of other thermal systems. It goes without saying, however, that the use of coal-fired boilers is definitely an outdated method.

Another solution that is characterized by low operating costs is a pellet-fired boiler. Pellet users appreciated its numerous advantages, which include: wide availability of the raw material on the market and competitiveness of its prices in relation to coal prices, high efficiency of pellet-fired boilers (usually above 90\%) and their high automation and maintenance-free (granulate charging is often only necessary). Pellets are also clean and non-staining fuel, and the emission of harmful substances to the atmosphere during combustion is negligible (www.muratorplus.pl).

The use of modern and unconventional methods of heating real estate, such as heat pumps (based on the use of renewable, free energy from the so-called lower heat sources), requires relatively high financial outlays for 
the purchase and installation of devices. Over time, however, low operating costs will translate into savings. In addition, such solutions are also characterized by great convenience and comfort of use. Undoubtedly, the attractiveness of using the so-called "Clean energy” in building heating has increased due to numerous government and EU programs supporting and subsidizing the use of unconventional heating methods that make a significant contribution to protecting the environment.

To sum up, the most advantageous methods of supplying heat for the needs of a building real estate, among those described in this paper and meeting the criterion of low operating costs, are two thermal systems: the use of a heat pump and a pellet-fired boiler. Both of these solutions are distinguished by modernity, ease of use, efficiency, high efficiency and care for the natural environment. Considering the above-mentioned characteristics of heating methods, they can be considered the most advantageous in selecting them as the optimal heating and building real estate method.

\section{Influence of building heating method on real estate value}

Many different factors influence the market value of a real estate building. Some of them determine the price of real estate more than others, so the impact is uneven. Such attributes include, among others: the location of the property, its area and cubature, the technical condition of the building, its surroundings and many others. One of the parameters significantly influencing the value of a residential building is the method of its heating. Therefore, when assessing the impact of heating conditions on the value of a building, one should focus on the specific object.

Currently, there are many ways to heat a property on the market. These systems are very different from each other on the following levels: general characteristics, type of fuels used, installation costs and everyday use. The advantages or disadvantages resulting from the specific use of the installed heating devices may encourage or scare a potential client considering purchasing a given property. Modern and effective technologies providing heat for the needs of residential buildings are, in this case, extremely desirable by buyers of single-family houses. The customer pays attention to the fact that the home heating installation generates future profits and savings and ensures comfort and convenience of use. The analysis indicates that, in addition to energy-efficiency measures regarding the building skin, a well-designed heating and ventilation system plays an important role in reducing financial costs and environmental impact over the lifespan of a dwelling (Debacker W. et al., 2013). For this reason, outdated, ineffective and requiring 
constant control central heating systems based on, e.g. tiled stoves or coalfired boilers, are not able to increase the value of a given property and usually lower it. In addition, a drop in the market price of a used building may be affected by the poor technical condition of the thermal installation and the need to replace or repair its individual components.

As already mentioned, the increase in the market price of real estate is positively influenced by the installation of modern and effective heating technologies, characterized by great convenience and ease of use. Furthermore, depending on the degree of availability of utilities (heat network, gas network), these can be heat systems powered by clean fuels, such as natural gas, LPG gas, heating oil, hot water from a combined heat and power plant, pellets and solar energy. Therefore, using any of the above-mentioned ecological heat sources contributes significantly to the increase in the value of the property and, at the same time, has a positive impact on the protection of the natural environment.

\section{Conclusions}

The article's main aim was to justify the hypothesis that the method of heating a building real estate has a significant impact on its market value. Considering the assumptions of the property valuation, the essence of the impact of the type of heating on the value of the building in question results from the analysis of energy raw materials and various heating systems available on the market. The sources of information on the current prices of heating devices and fuels were the data posted on the websites of energy suppliers or energy raw materials and internet offers of shops and distributors of heating devices.

This study attempts to indicate the most advantageous heating systems for residential buildings. One of the decisive criteria for the benefits of a specific heating system is low operating costs. Other factors contributing to the benefit of a given method of heating are efficiency and effectiveness of the heat source, ease of use, the comfort of use, environmental protection aspects and the financial profitability of the investment over the years. It was found to be modern and efficient heat sources are desired by potential property buyers and can significantly increase the value of a building. At the same time, obsolete heating methods, such as coal-fired boilers, for example, can lower. 


\section{Acknowledgements}

The research was carried out as part of study no. WZ/WB-IIL/6/2019 at the Bialystok University of Technology and financed from a subvention provided by the Minister of Science and Higher Education.

\section{References}

Adamczewski A., 2010. Wszystko co należy wiedzieć o biomasie, Doradca Energetyczny 6/2010.

Alimohammadisagvand B. et al., 2016, Cost-optimal thermal energy storage system for a residential building with heat pump heating and demand response control, Applied Energy, Volume 174, July 15 2016, Pages 275-287. DOI: https://doi. org/10.1016/j.apenergy.2016.04.013.

Announcement of the Marshal of the Sejm of the Republic of Poland of July 152003 on the publication of the uniform text of the Act - Energy Law (Consolidated text: Journal of Laws 2003 No. 153 item 1504).

Chen, L., Pan, W., 2015. A BIM-integrated Fuzzy Multi-criteria Decision Making Model for Selecting Low-Carbon Building Measures. Procedia Engineering, 118, 606613. DOI: https://doi.org/10.1016/j.proeng.2015.08.490.

Debacker W. et al., 2013. Identification of environmental and financial cost efficient heating and ventilation services for a typical residential building in Belgium, Journal of Cleaner Production, Volume 57, October 15 2013, Pages 188-199. DOI: https://doi.org/10.1016/j.jclepro.2013.05.037.

Gołąbeska E., 2019. The impact of the energy efficiency of the building to its market value, in: Ekonomia i Środowisko, nr 3 (70)/2019. DOI: 10.34659/2019/3/34.

Gołąbeska E., Drewnowska A., 2019, Stan techniczny budynku mieszkalnego w kontekście jego efektywności energetycznej, w: czasopismo C.H. Beck „Nieruchomości" 4/2019. DOI: 10.32027/NIER.19.4.11.

Juliszewski T., 2009. Ogrzewanie biomasą (Heating with biomass), Państwowe Wyd. Rolnicze i Leśne, Warszawa.

Kosieradzki J.,2009. Kotły kondensacyjne, Ekspert Budowlany 3(25)/2009.

Osterman E., Stritih U.. 2021. Review on compression heat pump systems with thermal energy storage for heating and cooling of buildings, Journal of Energy Storage, Volume 39, July 2021, 102569. DOI: https://doi.org/10.1016/j.est.2021. 102569.

Oszczak W., 2011. Ogrzewanie domów z zastosowaniem pomp ciepła (Heating houses with the use of heat pumps), Wyd. Komunikacji i Łączności, Warszawa.

Regulation of the Council of Ministers of September 21, 2004 on real estate valuation and preparation of an appraisal report (Journal of Laws 2004 no.207, item. 2109).

The Act of August 21, 1997 on real estate management (Consolidated text: Journal of Laws 1997 No.115, item 741).

The Act of April 231964 - Civil Code (Consolidated text: Journal of Laws 1964 No.16, item 93). 
Truong N., Gustavsson L. (2019), Costs and primary energy use of heating new residential areas with district heat or electric heat pumps, Energy Procedia, Volume 158, February 2019, Pages 2031-2038. DOI: https://doi.org/10.1016/j.egypro.2019.01.469.

www.budujemydom.pl, Is it profitable to install solar panels?

www.oferteo.pl, Heat pump - price. How much does a heat pump cost with assembly? www.muratorplus.pl, Pellets or wood granules: fashion or cool calculation?

www.tendeo.pl, Heat pump - price. How much does a heat pump cost with assembly? www.instalacjebudowlane.pl, What is the cost of solar collectors?

www.kb.pl, Solar colectors.

Zawistowski J., Janiszewski S., Jak wybrać kocioł?, Ekspert Budowlany 1(27)/2010. 